\title{
PROSPEK PENGEMBANGAN INDUSTRI KREATIF KULIT PARI SEBAGAI PILOT PROJECT USAHA KECIL DI DAERAH ISTIMEWA YOGYAKARTA
}

\author{
Meida Rositasari*, Latif Sahubawa, Siti Ari Budhiyanti \\ Departemen Perikanan, Fakultas Pertanian Universitas Gadjah Mada, Yogyakarta \\ Gedung A4, Jalan Flora No. 01 Bulaksumur, Yogyakarta 55281 \\ Korespondensi: meidarsts@gmail.com \\ Diterima: 29 Juni 2017 / Disetujui: 14 April 2018
}

Cara sitasi: Rositasari M, Sahubawa L, Budhiyanti SA. 2018. Prospek pengembangan industri kreatif kulit pari sebagai pilot project usaha kecil diDaerah Istimewa Yogyakarta. JurnalPengolahan Hasil Perikanan Indonesia. 21(1): 118-126.

\begin{abstract}
Abstrak
Industri kreatif merupakan kegiatan usaha yang fokus pada kreasi dan inovasi. Manajemen rantai pasok adalah jaringan perusahaan-perusahaan yang bekerjasama untuk menciptakan dan menghantarkan suatu produk ke tangan pemakai akhir. Penelitian bertujuan untuk mengkaji prospek pengembangan industri kreatif kulit pari di DIY sebagai pilot project usaha kecil di Indonesia. Metode pengumpulan data yang dipakai adalah observasi lapangan, wawancara dan kuesioner. Obyek penelitian adalah En't Stingray Product, Fanri Collection dan Pari Radja. Data hasil penelitian diolah dan dianalisis dengan metode kuantitatif dan kualitatif, selanjutnya digeneralisasi secara deskriptif. Hasil penelitian menunjukkan bahwa bahan baku kulit pari tersamak 75\% berasal dari supplier di Yogyakarta dan tersedia secara kontinu. Sarana dan prasarana usaha pengolahan produk cukup memadai. Produk yang dihasilkan berupa dompet pria dan wanita, gantungan kunci, tas, ikat pinggang dan gelang. Jaringan pemasaran produk kulit pari En't Stingray Product di Yogyakarta dan Jawa Tengah, Fanri Collection di Yogyakarta, Jakarta, Bandung, Surabaya, Pari Radja di seluruh Indonesia, Malaysia, Singapura, Jepang dan Amerika. Kelembagaan rantai pasok produk kulit terdiri dari supplier kulit segar, supplier kulit tersamak, pengrajin, reseller, konsumen. Berdasarkan hasil analisis kelayakan finansial, diketahui bahwa NPV En't Stingray Product yaitu Rp 75.312; Fanri Collection Rp 2.498.023; Pari Radja Rp 4.715.503 lebih besar dari nol. Prospek pengembangan industri produk kulit pari yang mencakup rantai pasok dan kelayakan usaha memberikan dampak yang positif terhadap pengembangan dan keberlanjutan usaha.
\end{abstract}

Kata kunci : industri kerajinan, kulit pari, rantai pasok, studi kelayakan

\section{Prospect of developing stingray leather creative industry as a pilot project of small business in Special Region of Yogyakarta}

\begin{abstract}
Creative industry is a business activity that focuses on creation and innovation. Supply chain management is a network of companies that work together to create and deliver a product into the hands of the end user. This research aims to examine the prospects for the developmnet of stingray creative industry in Special region of Yogyakarta as a pilot project of small business in Indonesia. Data collection methods used are field observation, interviews and questionnaires. The research object is En't Stingray Product, Fanri Collection and Pari Radja. Data of research result is processed and analyzed by quantitative and qualitative method, then descriptively. The results showed that the raw material of stinging leather $75 \%$ comes from suppliers in Yogyakarta and is available continuously. The facilities and business facilities of product processing are sufficient. Products produced in the form of man and woman wallets, key chains, bags, belts and bracelet. Network marketing of stingray products in En't Stingray Product in Yogyakarta and Cental Java; Fanri Collection in Yogyakarta, Jakarta, Surabaya, Bandung; Pari Radja in arround Indonesia, Malaysia, Singapura, Jepang and America. Institutional supply chain of stingray products consists of leather collectors, leather suppliers, product craftsmen, resellers, consumers. Based on the results of financial feasibility analysis, it is known that NPV En't Stingray Product $=\mathrm{Rp}$ 123.044; Fanri Collection $=\mathrm{Rp}$ 2.365.106; Pari Radja $=\mathrm{Rp}$ 4.715.503 greater than zero. Prospect of developing a stingray industry industry that includes supply chain and business feasibility has a positive impact on business development and sustainability.
\end{abstract}

Keywords: handicraft industry, stingray, supply chain, feasibility study. 


\section{PENDAHULUAN}

Produksi perikanan laut Indonesia pada tahun 2006 mencapai 4.512 .191 ton dan meningkat menjadi 6.351 .480 ton pada Tahun 2016. Perkembangan produksi perikanan tangkap laut selama periode 20062016 cenderung meningkat (KKP 2016). Sumberdaya perikanan terdiri dari jenis ikan ekonomis penting dan non ekonomis (KKP 2015). Ikan pari termasuk jenis ikan ekonomis penting, tetapi tidak disukai konsumen karena dagingnya mengandung urea dalam jumlah besar dan menimbulkan bau pesing yang tajam, meskipun demikian kulit permukaannya dapat dimanfaatkan sebagai bahan baku produk kreatif kulit yang sangat menarik dengan harga yang kompetitif dan sangat disukai oleh konsumen. Berdasarkan hasil observasi, daging segar dijual dengan harga yang sangat murah (hanya Rp 4.000-5.000/kg). Ikan pari secara umum dimanfaatkan menjadi beragam produk olahan, antara lain daging asap, dendeng kering, abondan dendeng asin.

Perkembangan dan kemajuan teknologi, seni dan inovasi di bidang industri perkulitan dapat meningkatkan nilai tambah dari kulit pari melalui proses pengolahan kulit segar menjadi kulit samak sebagai bahan baku produk kreatif kulit komersial. Usaha pengolahan kulit pari yang berkembang saat ini sebagian besar masih pada skala Usaha Mikro-Kecil (UMK), namun melihat prospek pasar dan permintaan konsumen yang cukup besar maka industri produk kreatif kulit pari berpeluang untuk dikembangkan pada skala menengah dan besar. Produk yang dihasilkan antara lain dompet untuk laki-laki dan wanita, gantungan kunci, tas, ikat pinggang dan gelang. Produk kreatif kulit pari tergolong produk komersial yang unik dan menarik serta hampir tidak pernah ditemui di berbagai pasar kulit di belahan dunia lainnya. Dengan karakteristik produk yang dimiliki (unik, menarik, produk baru, awet, sebagai barang dan aksesoris mahal), maka dengan kemajuan Iptek dibidang IT (menggunakan sistem pemasaran online), produk kreatif kulit pari dapat dipasarkan secara luas (pasar global) yang memudahkan konsumen internasional mengakses secara cepat (Sahubawa 2017).
Beberapa kendala yang dihadapi UMK produk kulit pari, antara lain keterbatasan bahan baku kulit pari segar, keterbatasan produksi kulit jadi/kulit samak (bahan baku produk dan barang kulit) sesuai permintaan industri serta mutu dan ukuran kulit samak yang beragam dalam cakupan Manajeman Rantai Pasok (MRP).

MRP merupakan salah satu mekanisme untuk meningkatkan produktivitas perusahaan. MRP merupakan fungsi bisnis yang penting untuk mengkoordinasikan pengelolaan barang sebagai kunci kompetisi (Siahaya 2013). Kulit pari memiliki karakteristik unik yang berbeda dengan produk kulit konvensional (kulit sapi, kerbau, domba, kuda dan sejenisnya) yaitu memiliki manik-manik di seluruh permukaan kulit serta mutiara yang terletak di sepanjang garis tengah dan bagian tengah kulit (Sahubawa et al. 2010). Penelitian ini bertujuan untuk untuk mengkaji prospek pengembangan industri kreatif kulit pari di DIY sebagai pilot project usaha kecil di Indonesia.

\section{BAHAN DAN METODE}

Penelitian dilakukan di 3 (tiga) UMK kerajinan produk kreatif kulit pari di Daerah Istimewa Yogyakarta yaitu En't Stingray Product, Fanri Collection dan Pari Radja. Pengumpulan data menggunakan metode observasi lapangan, wawancara, kuesioner terhadap pemilik usaha, tenaga kerja, suplier bahan baku (kulit tersamak) dan konsumen. Jumlah responden (untuk preferensi konsumen) sebanyak 70 orang dengan metode acak sederhana. Responden konsumen merupakan pemakai produk kulit pari. Data hasil penelitian diolah dan dianalisis dengan metode kuantitatif dan kualitatif, selanjutnya digeneralisasi secara deskriptif. Analisis deskriptif merupakan analisis data yang dimulai dari menelaah seluruh data dari hasil observasi, wawancara dan dokumentasi. Analisis data bersifat menguraikan, menafsirkan dan menggambarkan data yang diperoleh secara sistematis. Indikator yang dikaji pada analisis kelayakan finansial usaha adalah Net Present Value (NPV), Net B/C ratio, Internal Rate of Return (IRR), Pay Back Period (PBP) dan Break Even Point (BEP). 


\section{Net Present Value (NPV)} berikut.

Bentuk matematis dari NVP sebagai

$$
N P V=\sum_{t=i}^{n} \frac{(B t-C t)}{(1+i)^{t}}
$$

Keterangan

Bt : Penerimaan proyek pada tahun ke-t

Ct : Biaya proyek pada tahun ke-t

n : Umur ekonomis proyek

i $\quad$ : Tingkat suku bunga kredit investasi

Indikator kelayakannya adalah: jika NPVbernilai positif $(\mathrm{NPV}>0)$ maka usaha layak untuk dijalankan, jika NPV bernilai negatif $(\mathrm{NPV}<0)$ maka usaha tidak layak untuk dijalankan.

\section{Net $B / C$ ratio}

Model matematis dari Net $B / C$ ratio adalah sebagai berikut.

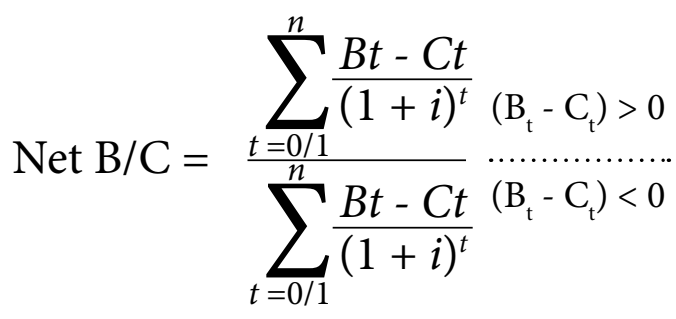

Keterangan.

Bt : Penerimaan proyek pada tahun ke-t

Ct : Biaya proyek pada tahun ke-t

Jika Net B/C> 1,0 maka UMK dinyatakan layak, sebaliknya jika Net $\mathrm{B} / \mathrm{C}<1,0$ maka usaha tidak layak.

\section{Internal Rate of Return (IRR)}

Model matematis dari Internal Rate of Return (IRR) adalah sebagai berikut.

$$
I R R=\frac{N P V 1}{(N P V 1-N P V 2)} i 1(\mathrm{i} 2-\mathrm{i} 1)
$$

Keterangan.

i1 : Nilai suku bunga pertama

i2 : Nilai suku bunga kedua

NPV1 dan NPV2, salah satunya adalah negatif Jika IRR > suku bunga bank yang berlaku $(I R R>D R)$ maka usaha layak untuk dikembangkan, sebaliknya jika $I R R<$ suku bunga yang berlaku $(I R R<D R)$ maka usaha tidak layak untuk dikembangkan.

\section{Pay Back Period (PBP)}

Model matematis dari PBP adalah sebagai berikut.

$$
\text { Payback Period } \frac{\text { Initial Investmen }}{\text { Cash Flow }} \times 1 \text { Tahun }
$$

Kriteria Pay Back Period tidak memiliki indikator standar dan bersifat relatif, tergantung umur proyek dan besarnya investasi. Usaha layak dijalankan jika PBP usaha tidak terlalu lama mendekati akhir proyek atau lebih lama dari umur proyek. PBP yang relatif cepat lebih disukai untuk investasi.

\section{HASIL DAN PEMBAHASAN Profil Usaha}

Industri yang digunakan sebagai obyek penelitian adalah En't Stingray Product, Fanri Collection dan Pari Radja. Ketiga industri sudah berdiri lebih dari sepuluh tahun. Jumlah tenaga kerja pada industri ini berkisar $4-15$ orang. Hal ini sesuai dengan skala usahanya yang bergerak dalam lingkup usaha kecil, sehingga tidak banyak membutuhkan tenaga kerja. Kualifikasi pendidikan tenaga kerja merupakan lulusan SMP, SMA/K dan pendidikan informal. Status pekerja mulai dari pekerja tetap, lepas/harian dan borongan. Status pekerja di En’t Stingray Product bersifat borongan. Tenaga kerja borongan merupakan tenaga kerja yang bekerja untuk melakukan pekerjaan tertentu dengan menerima upah berdasarkan volume pekerjaan atau satuan hasil kerja. Tenaga kerja borongan bersifat efektif karena tenaga kerja akan lebih bersemangat dalam melakukan pekerjaan karena mereka mempunyai target produk yang harus diselesaikan (Daniel 2009). Tenaga kerja di Fanri Collection bersifat tetap dan di Pari Radja bersifat lepas/harian. Tenaga kerja di Fanri Collection sebagian besar merupakan penyandang disabilitas, sehingga mobilitas bekerja terbatas. Pari Radja tidak mengutamakan keterampilan tetapi tenaga kerja harus memiliki etos kerja dan kreativitas. Jumlah tenaga kerja di En't Stingray Product paling sedikit, hal ini dikaitkan dengan kapasitas produk yang dihasilkan. Ketiga profil usaha industri kerajinan produk kreatif kulit pari komersial diuraikan pada Tabel 1 . 
Tabel 1 Profil UMK kerajinan produk dan barang kulit pari di Daerah Istimewa Yogyakarta (Table 1 Profile of SME handicraft products from skin stingray in Yogyakarta Region)

\begin{tabular}{|c|c|c|c|c|c|c|c|c|c|c|}
\hline No & $\begin{array}{l}\text { Industry } \\
\text { Name }\end{array}$ & $\begin{array}{c}\text { Year } \\
\text { started }\end{array}$ & $\begin{array}{c}\text { Long } \\
\text { business } \\
\text { (Year) }\end{array}$ & Address & $\begin{array}{l}\text { Number } \\
\text { of Labor } \\
\text { (people) }\end{array}$ & $\begin{array}{c}\text { Source } \\
\text { of Raw } \\
\text { Material } \\
\text { (Stingray) }\end{array}$ & $\begin{array}{l}\text { Types of } \\
\text { products }\end{array}$ & $\begin{array}{c}\text { Production } \\
\text { Capacity } \\
\text { (item / } \\
\text { month) }\end{array}$ & $\begin{array}{c}\text { Network } \\
\text { Marketing }\end{array}$ & $\begin{array}{c}\text { Sales turnover } \\
\text { (Rp/Year) }\end{array}$ \\
\hline 1 & $\begin{array}{l}\text { En't } \\
\text { Stingray } \\
\text { Product }\end{array}$ & 2005 & 12 & $\begin{array}{c}\text { Sumberan, } \\
\text { Tamantirto } \\
\text { Kasihan } \\
\text { Bantul }\end{array}$ & 4 & Yogyakarta & $\begin{array}{l}\text { man's wallet } \\
\text { Women's wallet } \\
\text { key chain }\end{array}$ & $\begin{array}{c}100 \\
70 \\
100\end{array}$ & $\begin{array}{l}\text { Yogya } \\
\text { \& Jawa } \\
\text { Tengah }\end{array}$ & 24.613 .133 \\
\hline 2 & $\begin{array}{l}\text { Fanri } \\
\text { Collection }\end{array}$ & 1996 & 21 & $\begin{array}{c}\text { Jalan } \\
\text { Kaliurang } \\
\text { Km. 13,5 } \\
\text { Ngaglik } \\
\text { Sleman }\end{array}$ & 15 & $\begin{array}{c}\text { Yogyakarta, } \\
\text { Rembang, } \\
\text { Pati, } \\
\text { Cilacap }\end{array}$ & $\begin{array}{l}\text { man's wallet } \\
\text { Women's wallet } \\
\text { key chain } \\
\text { bag } \\
\text { belt } \\
\text { Bracelet }\end{array}$ & $\begin{array}{c}300 \\
250 \\
100 \\
5 \\
20 \\
50\end{array}$ & $\begin{array}{l}\text { Yogya, } \\
\text { Jakarta, } \\
\text { Bandung, } \\
\text { Surabaya }\end{array}$ & 816.404 .033 \\
\hline 3 & Pari Radja & 2003 & 14 & $\begin{array}{c}\text { Jalan } \\
\text { Parangtritis } \\
\text { Km. } 8 \\
\text { Dadapan, } \\
\text { Sewon } \\
\text { Bantul }\end{array}$ & 13 & $\begin{array}{c}\text { Yogyakarta } \\
\text { and } \\
\text { Magetan }\end{array}$ & $\begin{array}{l}\text { man's wallet } \\
\text { Women's wallet } \\
\text { key chain } \\
\text { bag } \\
\text { belt } \\
\text { Gelang }\end{array}$ & $\begin{array}{c}200 \\
200 \\
100 \\
5 \\
20 \\
350\end{array}$ & $\begin{array}{l}\text { Indonesia } \\
\text { Malaysia, } \\
\text { Jepang, } \\
\text { Amerika, } \\
\text { Singapura }\end{array}$ & 1.541 .120 .773 \\
\hline
\end{tabular}

Berdasarkan Tabel 1 terlihatbahwasumber bahan baku kulit tersamak 75\% diperoleh dari Yogyakarta (Moyudan, Godean). Beberapa diperoleh dari supplier luar Yogyakarta sebagai cara untuk mengantisipasi apabila terjadi kelangkaan bahan baku sehingga proses produksi tetap berjalan secara kontinu. Jenis kulit pari yang digunakan antara lain batu halus, mondol, cingir dan duri. Ketersediaan bahan baku selama ini masih mencukupi.

En't Stingray Product dan Fanri Collection memperoleh bahan baku berupa kulit tersamak, sedangkan di Pari Radja berupa kulit mentah dan kulit tersamak, apabila sedang ada order yang mendesak dan kulit tersamak tidak mencukupi, Pari Radja melakukan proses penyamakan kulit sendiri. Kulit segar diperoleh dari Magetan. Kendala yang dihadapi apabila kulit segar adalah mutu kurang terjamin karena harus segera disamak dan harus didatangkan dari luar daerah. Jenis produk yang dihasilkan dari ketiga industri cenderung sama, yaitu dompet untuk laki-laki dan wanita, gantungan kunci, tas, ikat pinggang dan gelang. Produksi tas, ikat pinggang dan gelang disesuaikan dengan permintaan konsumen. Kapasitas produksi paling besar adalah Pari Radja. Hal ini karena industri tersebut telah mempunyai jaringan pasar yang luas dan tenaga kerja yang cukup banyak. Secara umum, kendala yang dihadapi adalah kurangnya desain/model yang terbaru, sehingga pengrajin harus lebih kreatif dalam mendesain. Jaringan pemasaran En't Stingray Product dan Fanri Collection masih lokal, sedangkan Pari Radja sudah merambah ke luar negeri. Sistem promosi Pari Radjasudah secara online (email, media sosial). Sistem pemasaran dapat memberikan pengaruh terhadap hubungan industri dengan pasarnya. Berdasarkan distribusi produknya, konsumen produk kulit pari dibedakan menjadi dua kelompok, yaitu menjual kepada konsumen melalui toko milik sendiri/penjualan online/ pesanan dan menjual kepada distributor (reseller). Kapasitas produksi dan jaringan mempengaruhi omset/pendapatan industri. Omset terendah adalah En't Stingray Product dan tertinggi adalah Pari Radja. Kendala yang dihadapi masing-masing industri berbeda, antara lain En't Stingray Product kurang jaringan pemasaran dan belum adanya show room, Fanri Collection masih kekurangan tenaga kerja dan pemasaran, kendala Pari Radja adalah peralatan/mesin produksi yang sering rusak karena sudah melampaui umur teknisnya.

\section{Manajemen Rantai Pasok}

Manajemen rantai pasok adalah jaringan perusahaan-perusahaan yang bekerjasama untuk menciptakan dan menghantarkan 
suatu produk ke tangan pemakai akhir (Pujawan 2005). Secara umum jalur rantai pasok yang digunakan adalah dari supplier kulit segar, supplier kulit tersamak, pengrajin/ industri, reseller, konsumen. Gambaran rantai pasok produk kulit pari dapat dilihat pada Gambar 1.

Berdasarkan Gambar 1, kelembagaan rantai pasok bahan baku kulit pari segar diperoleh dari supplier kulit di daerah Semarang, Tegal, Jepara dengan kisaran 4.000 lembar/bulan, setelah menjadi kulit pari tersamak, kulit dipasarkan kepada pengrajin produk kulit di daerah Yogyakarta dan Jawa Tengah. Distribusi bahan baku dari kulit segar sampai ke produk kadang mengalami ketidak seimbangan. Hal ini dikarenakan dari supplier kulit segar memasok kulit segar ke penyamak dalam jumlah yang besar dan rutin setiap minggu, sedangkan jumlah kulit tersamak yang disetor ke pengrajin tidak menentu sesuai kebutuhan industri. Hal ini dikarenakan jumlah pengrajin produk kulit masih sedikit dan harga produk kulit pari cenderung tinggi.

Berdasarkan Gambar 1 terlihat bahwa rantai pasok bahan baku kulit diperoleh dari supplier kulit segar, kemudian di samak oleh supplier kulit samak, dilakukan proses produksi (pemilihan kualitas bahan baku, pembuatan desain, pengguntingan pola, penggrendaan, penghalusan, pengecatan, pemotongan pola, pembentukan produk, penjahitan, finishing) kemudian dipasarkan dengan jangkauan lokal, nasional, regional dan internasional. En't Stingray Product memperoleh kulit samak dari Yogyakarta sebanyak 400 lembar/bulan. Kulit samak diolah menjadi produk dompet laki-laki (100 buah/bulan) dan wanita (70 buah/bulan), gantungan kunci (100 buah/bulan). Produk yang sudah jadi dipasarkan kepada reseller dan konsumen di wilayah Yogyakarta dan Jawa Tengah.

Rantai pasok produk kulit pari di Fanri Collectiondimulai dari kulit samak, pengrajin, reseller dan konsumen. Fanri Collection mendapatkan kulit langsung dari supplier kulit samak karena tidak mempunyai peralatan proses penyamakan dan fokus untuk mengolah produk. Fanri Collection memperoleh kulit samak dari Yogyakarta (500 lembar/bulan), Jawa Tengah (Rembang, Pati, Cilacap sebanyak 500 lembar/bulan). Fanri Collection mengolah kulit samak menjadi produk kulit berupa dompet laki-laki (300 buah/bulan), dompet wanita (250 buah/ bulan), gantungan kunci (100 buah/lembar), tas ( 5 buah/lembar), ikat pinggang (20 buah/ bulan), gelang (50 buah/bulan). Produk kulit pari dipasarkan di Yogyakarta dan sekitarnya, Jakarta, Bandung, Surabaya.

Rantai pasok produk kulit pari di Pari Radja dimulai dari bahan baku kulit samak dari supplier. Kelembagaan rantai pasok produk kulit di Pari Radja terdiri dari supplier kulit samak, pengrajin, konsumen. Kulit samak diperoleh dari Yogyakarta (500 lembar/ bulan) dan Magetan (200 lembar/bulan). Kulit samak diolah menjadi produk kulit berupa dompet laki-laki (200 buah/bulan), dompet wanita (200 buah/bulan), gantungan kunci (100 buah/bulan), tas (5 buah/bulan), ikat pinggang (20buah/bulan), gelang (350 buah/ bulan). Pari Radja menjual produk langsung ke konsumen akhir. Hal ini dikarenakan untuk mengantisipasi persaingan harga. Produk jadi dipasarkan di seluruh Indonesia, Malaysia, Singapura, Jepang, Amerika. Aliran uang ketiga industri produk kulit pari dilakukan secara tunai dan non tunai (secara langsung

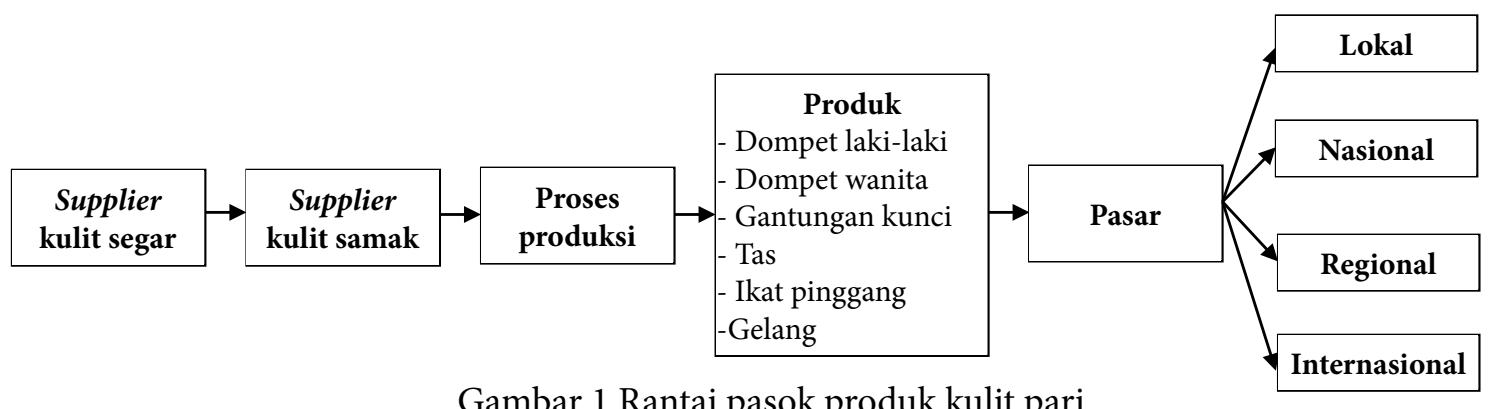

Gambar 1 Rantai pasok produk kulit pari

(Figure 1 Supply chain of stingray leather products) 
atau transfer) dan aliran informasi berjalan dari hulu ke hilir dan sebaliknya (pengepul kulit sampai konsumen terakhir dan konsumen terakhir sampai pengepul kulit).

Keberhasilan suatu usaha dalam kerangka rantai pasok dapat didekati dengan memperhatikan prinsip manajemen rantai pasok, antara lain memahami pelanggan dan konsumen dengan benar, menyediakan produk dengan benar, menciptakan dan membagikan profit margin kepada semua rantai, logistik dan distribusi yang memadai, komunikasi dan informasi yang lancar, hubungan yang efektif antar pelaku rantai pasok (Yusuf 2012).

Manajemen rantai pasok tidak hanya berorientasi pada urusan internal sebuah perusahaan/industri, melainkan juga urusan eksternal yang menyangkut hubungan dengan perusahaan partner. Koordinasi dan kolaborasi perlu dilakukan karena perusahaan yang berada pada satu supply chain pada intinya ingin memuaskan konsumen akhir yang sama, sehingga mereka harus bekerja sama untuk membuat produk yang berkualitas dan mengirim tepat waktu (Mulyadi 2011).

\section{Preferensi Konsumen}

Preferensi konsumen merupakan hal yang penting dalam pemasaran karena berhubungan erat dengan keberhasilan industri untuk mencapai tujuannya yaitu keputusan pembelian yang dilakukan oleh konsumen atas dasar preferensi konsumen (Yanuasti 2016). Preferensi konsumen terhadap atribut mutu produk kulit pari merupakan salah satu data yang dapat digunakan dalam mengevaluasi aspek pasar dari industri kerajinan produk kulit pari. Responden yang digunakan dalam penelitian ini merupakan konsumen atau pemakai produk kulit pari. Total responden yang digunakan sebanyak 70 orang. Gambaran umum karakteristik responden dapat dilihat pada Gambar 2.

Berdasarkan Gambar 2, produk yang paling banyak dibeli oleh konsumen adalah dompet laki-laki. Karakteristik responden tentang uji kesukaan menunjukkan bahwa sebagian besar responden sudah mengetahui produk kulit pari tersebut. Hal tersebut menandakan bahwa strategi pemasaran yang dilakukan industri cukup efektif dengan jangkauan distribusi yang masih terbatas lokal, oleh karena itu, masih diperlukan strategi pengembangan pasar.

Uji kesukaan konsumen digunakan untuk mengetahui penerimaan konsumen terhadap atribut mutu produk kulit (kualitas, harga, bentuk, warna, kemasan) dan faktor pemilihan lokasi yang mempengaruhi konsumen untuk membeli produk (seperti diskon, promosi, pelayanan dan akses lokasi). Hasil penerimaan konsumen digunakan sebagai referensi untuk tindakan perbaikan masa mendatang. Berdasarkan data hasil olahan kuesioner, penilaian responden terhadap atribut mutu dan pemilihan lokasi dapat dilihat pada Tabel 2.

Berdasarkan Tabel 2 terlihat bahwa

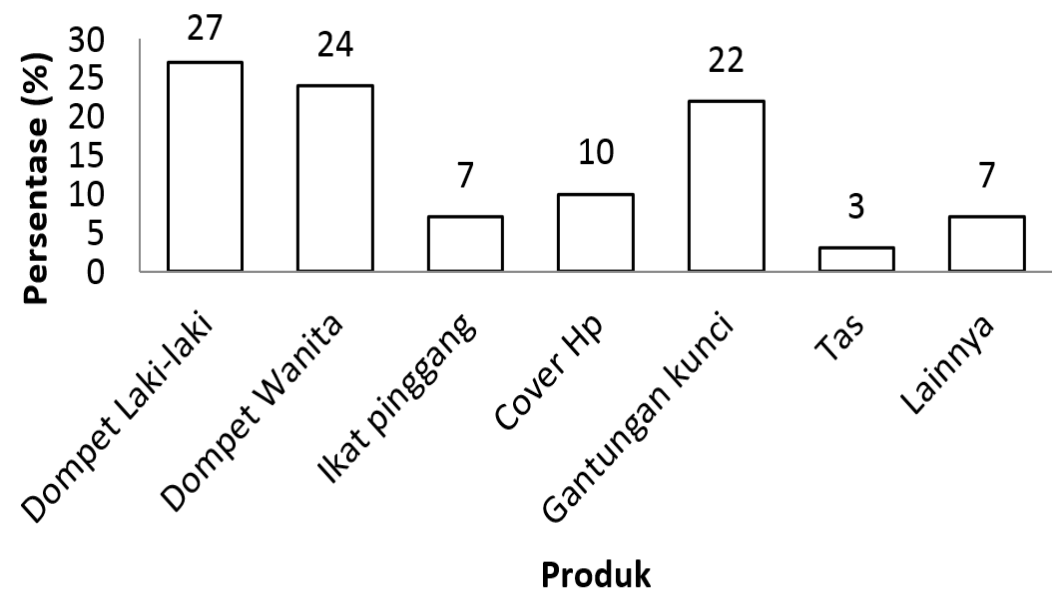

Gambar 2 Jenis produk yang dibeli konsumen

(Figure 2 Types of products purchased by consumers) 
Tabel 2 Penilaian responden terhadap atribut mutu dan pemilihan lokasi

(Table 2 Assessment of respondents to quality attributes and site selection)

\begin{tabular}{cccccccccc}
\hline $\begin{array}{c}\text { Attribute/ } \\
\text { Assessment }\end{array}$ & Quality & Price & Color & Form & Packaging & Discount & Promotion & $\begin{array}{c}\text { Access } \\
\text { Location }\end{array}$ & Services \\
\hline $\begin{array}{c}\text { Very } \\
\text { important (\%) }\end{array}$ & 41 & 11 & 27 & 16 & 13 & 41 & 30 & 21 & 34 \\
$\begin{array}{c}\text { Important } \\
\text { (\%) }\end{array}$ & 50 & 60 & 63 & 60 & 69 & 47 & 60 & 63 & 56 \\
$\begin{array}{c}\text { Usual (\%) } \\
\text { Secondry (\%) }\end{array}$ & 6 & 26 & 6 & 20 & 14 & 7 & 6 & 13 & 7 \\
$\begin{array}{c}\text { Unimportant } \\
\text { (\%) }\end{array}$ & 0 & 0 & 1 & 1 & 0 & 2 & 0 & 1 & 3 \\
Total (\%) & 100 & 100 & 100 & 100 & 100 & 100 & 100 & 100 & 100 \\
\hline
\end{tabular}

sebagian besar responden dari jumlah 70 orang memberikan penilaian penting terhadap atribut mutu dan pemilihan lokasi pembelian produk. Kualitas menjadi hal penting dalam membeli produk. Kualitas yang baik dapat meningkatkan reputasi industri dan kesempatan mewujudkan cost reduction. Industri yang menciptakan produk berkualitas, akan mendapatkan predikat yang bagus di mata pelanggan. Harga yang ditawarkan juga dinilai penting, artinya responden berharap harga yang ditawarkan bisa lebih terjangkau oleh semua kalangan. Konsumen pada umumnya mengharapkan produk yang akan dibeli memiliki harga yang terjangkau dengan kualitas yang baik. Warna dan bentuk tergantung pada selera konsumen. Warna dan bentuk produk bisa dijadikan sebagai alat untuk berinovasi, sehingga dapat menarik perhatian konsumen. Kemasan juga menjadi hal yang penting karena konsumen beranggapan bahwa kemasan yang baik mencerminkan mutu yang baik dan dapat memberikan nilai tambah estetika pada produk. Kemasan produk memiliki kegunaan untuk melindungi, memfasilitasi penggunaan, sebagai media promosi dan menyediakan informasi mengenai suatu produk. Faktor penting dalam pemilihan lokasi pembelian produk antara lain adanya diskon, promosi, akses lokasi dan pelayanan yang baik dari industri. Akses lokasi yang mudah dijangkau dan strategis akan mempengaruhi jumlah konsumen yang datang, promosi dengan media sosial akan mempermudah masyarakat untuk membeli produk, pelayanan yang baik akan memberikan dampak yang baik terhadap suatu industri dan adanya diskon yang diberikan menjadi salah satu cara pemasaran yang menarik karena dapat menarik perhatian pengunjung. Konsumen juga memberikan saran perbaikan untuk produk kulit pari, antara lain pengembangan desain/ inovasi produk, harga dapat terjangkau oleh masyarakat, peningkatan promosi di dalam/ luar negeri, peningkatan kualitas produk, bentuk model lebih variatif.

\section{Kelayakan Usaha}

Analisis kelayakan usaha dilakukan untuk mengetahui apakah usaha kerajinan produk kulit pari ini mendatangkan keuntungan atau tidak. Analisis ini menggunakan asumsi sebagai berikut. Umur proyek ditetapkan selama 10 tahun karena dianggap dapat mempresentasikan kondisi usaha yang dijalankan, biaya investasi di asumsikan dikeluarkan pada tahun ke-0, daftar nilai investasi awal (lahan atau bangunan dan peralatan produksi) adalah harga sekarang (2017), suku bunga yang dijadikan dasar dalam perhitungan analisis kelayakan pada penelitian ini adalah suku bunga BI tahun 2017 (4,75\%), kegiatan produksi yang dilakukan di industri tersebut diasumsikan tetap setiap bulannya, perhitungan analisis kelayakan usaha menggunakan data produksi, yang diasumsikan semua produk laku terjual setiap bulannya, perhitungan biaya bahan baku mengikuti harga sekarang (2017) berdasarkan keterangan dari pemilik usaha. Hasil perhitungan analisis kelayakan usaha dapat dilihat pada Tabel 3 berikut. 
Tabel 3 Analisa kelayakan usaha industri kerajinan produk kulit pari (Table 3 Feasibility analysis of rattan products industry)

\begin{tabular}{ccccccc}
\hline \multirow{2}{*}{$\begin{array}{c}\text { Nama Usaha/ } \\
\text { Business Name }\end{array}$} & NPV (Rp) & $\begin{array}{c}\text { Net B/C } \\
\text { ratio }\end{array}$ & IRR (\%) & PBP & BEP & Outcome \\
\hline $\begin{array}{c}\text { En't Stingray } \\
\text { Product } \\
\begin{array}{c}\text { Fanri } \\
\text { Collection }\end{array}\end{array}$ & 75.312 & 2,28 & 27 & $\begin{array}{c}1 \text { month } 26 \\
\text { days }\end{array}$ & $\begin{array}{c}9 \text { years } 8 \\
\text { months }\end{array}$ & Worthy \\
Pari Radja & 4.498 .023 & 28,50 & 365 & $\begin{array}{c}\text { month } 1 \\
\text { days }\end{array}$ & $\begin{array}{c}7 \text { years } 6 \\
\text { months }\end{array}$ & Worthy \\
\hline
\end{tabular}

\section{Net Present Value (NPV)}

Nilai NPV yang positif menunjukkan bahwa proyek atau industri tersebut layak dijalankan. Tabel 3 menunjukkan bahwa hasil NPV En't Stingray Product Rp 75.312, Fanri Collection Rp 2.498.023 dan Pari Radja Rp 4.715.503 menunjukkan hasil positif (NPV > 0 ), artinya ketiga usaha tersebut layak untuk dijalankan (Husein 2005).

\section{Net $B / C$ ratio}

Net $B / C$ ratio menunjukkan kemampuan menghasilkan laba per satuan nilai investasi. Berdasarkan Tabel 3 terlihat bahwa nilai Net $B / C$ ratio En't Stingray Product 2,28, Fanri Collection 28,50 dan Pari Radja 15,14. Hal ini menunjukkan bahwa nilai perbandingan penerimaan dari usaha lebih besar daripada jumlah biaya yang dikeluarkan untuk memperolehnya, atau industri tersebut akan mendapat tambahan penerimaan $(\operatorname{Rp} 2,28$; Rp 28,50; Rp 15,14) dari setiap pengeluaran Rp 1,00. Nilai Net B/C ratio ketiga industri $>$ 1 , artinya ketiga usaha layak untuk dijalankan (Khotimah et al. 2014).

\section{Internal Rate of Return (IRR)}

Berdasarkan Tabel 3 terlihat bahwa nilai IRR En't Stingray Product 27\%, Fanri Collection 365\% dan Pari Radja 194\%. IRR digunakan untuk melihat seberapa besar pengembalian usaha terhadap investasi yang ditanamkan. Kriteria kelayakan dilakukan dengan membandingkan nilai IRR dengan tingkat suku bunga yang digunakan $(4,75 \%)$. Nilai IRR ketiga industri menunjukkan lebih dari discount rate, artinya ketiga usaha tersebut layak untuk dijalankan.

\section{Pay Back Period (PBP)}

Analisis pay back period digunakan untuk mengukur seberapa cepat pengembalian investasi pada suatu usaha. Tabel 3 menunjukkan bahwa nilai PBP En't Stingray Product 1 bulan 26 hari, Fanri Collection 1 bulan 1 hari dan Pari Radja 3 bulan. Hasil analisa menyatakan bahwa ketiga industri memiliki jangka waktu pengembalian modal investasi yang digunakan untuk membiayai bisnis membutuhkan waktu yang singkat (pada tahun pertama). Berdasarkan kriteria investasi PBP masih dalam umur proyek, sehingga usaha ini layak untuk dijalankan.

\section{Break Even Point (BEP)}

BEP untuk usaha ini merupakan nilai yang menunjukkan waktu pengembalian investasi. Berdasarkan Tabel 3 terlihat bahwa BEP En't Stingray Product akan mengalami pengembalian investasi 9 tahun 8 bulan, Fanri Collection 7 tahun 6 bulan dan Pari Radja5 tahun. Nilai BEP tersingkat adalah Pari Radja dan yang terlama adalah En't Stingray product. Hal ini dikarenakan penerimaan atau pendapatan di Pari Radja lebih tinggi.

Berdasarkan Tabel 3 terlihat bahwa kriteria investasi ketiga industri menunjukkan bahwa usaha kerajinan kulit pari secara finansial menjanjikan keuntungan. Selain keuntungan finansial yang akan didapatkan dari industri ini, ada berbagai keuntungan lainnya seperti peningkatan nilai tambah (value added) kulit pari, meningkatkan kualitas produk kulit, menunjang industri produk kulit pari dengan tersedianya kulit berkualitas dan sesuai spesifikasi pasar dan memberi dampak ekonomi bagi masyarakat 
sekitar industri dengan menyerap tenaga kerja.

\section{KESIMPULAN}

Rantaipasokprodukkulit paridimulaidari pasokan kulit segar/mentah, kulit tersamak, proses produksi dan pasar/pemasaran. Berdasarkan hasil analisis kelayakan finansial, diketahui NPV En't Stingray Product Rp 75.312; Fanri CollectionRp 2.498.023; Pari Radja Rp 4.715.503 lebih besar dari nol. Prospek pengembangan industri produk kulit pari yang mencakup rantai pasok dan kelayakan usaha memberikan dampak yang positif terhadap pengembangan dan keberlanjutan usaha.

\section{DAFTAR PUSTAKA}

Daniel. 2009. Produktivitas tenaga kerja outsourcing/tenaga kerja kontrak yang mempengaruhi kinerja waktu dalam proyek konstruksi. [Tesis]. Jakarta (ID): Universitas Indonesia.

Husein U. 2005. Riset Pemasaran dan Perilaku Konsumen. Jakarta (ID): Gramedia.

[KKP] Kementerian Kelautan dan Perikanan. 2015. Ikan-ikan Ekonomis Penting di Indonesia. Jakarta (ID): Kementerian Kelautan dan Perikanan.

[KKP] Kementerian Kelautan dan Perikanan. 2016. Statistik Perikanan Tangkap Indonesia. Jakarta (ID): Kementerian Kelautan dan Perikanan.

Khotimah H, Sutiono. 2014. Analisis kelayakan finansial usaha budidaya bambu. Jurnal ilmu kehutanan. 8(1): 14-24.
Mulyadi D. 2011. Pengembangan sistem logistik yang efisien danefektif dengan pendekatan supply chain management. Jurnal Riset Industri. 5(3): 275-282.

Pujawan N. 2005. Supply Chain Management Edisi Pertama. Surabaya (ID): Gunawidya.

Sahubawa L, Pertiwiningrum A, Pamungkas AT. 2010. Pengaruh kombinasi bahan penyamak formalin dan syntan terhadap kualitas kulit ikan pari tersamak. Majalah Kulit, Karet dan Plastik. 27(1): 38-45.

Sahubawa L. 2017. Produk Inovasi Teknologi: Desain dan Pengembangan Produk Kreatif Kulit Ikan Pari Komersial Berbasis Ekspor. [Laporan]. Yogyakarta (ID). Direktorat Penelitian Universitas Gadjah Mada.

Siahaya W. 2013. Sukses Supply Chain Management, Akses Demand Chain Management. Jakarta (ID): In Media.

Yanuasti N. 2016. Analisis critical success factor pelaksanaan manajemen rantai pasok dan pengaruhnya terhadap performa usaha mikro kecil olahan ikan di Kabupaten Sleman. [Skripsi]. Yogyakarta (ID): Universitas Gadjah Mada.

Yusuf. 2012. Analisis produksi dan pemasaran dalam kerangka supply chain management jeruk keprok soe di Kabupaten Timor Tengah Selatan. [Disertasi]. Yogyakarta (ID): Universitas Gadjah Mada. 